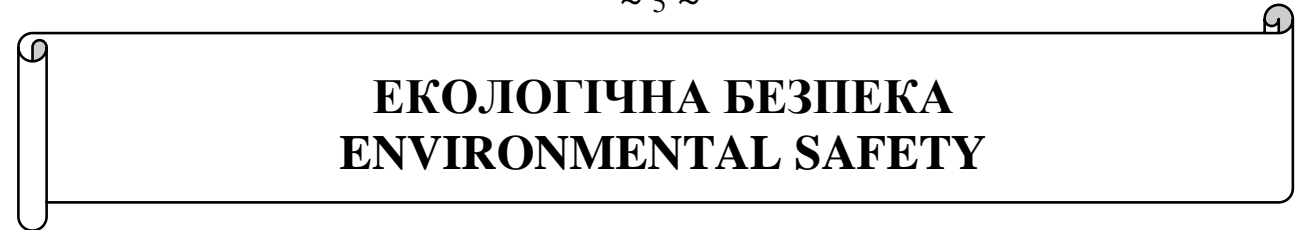

UDC 631.6

Mustafa Gilman Mustafayev, D. S. (Agrarian), Associate Professor ORCID ID 0000-0003-2071-3078 e-mail:meliorasiya58@mail.ru

Bakhtiyar Mursal Mammadov, $\mathrm{PhD}$

Nisa Mustafa Huseynova, Research Scientist

Institute of Soil Science and Agrochemistry of the National Academy of Sciences of Azerbaijan, Baku, Azerbaijan

\title{
AMELIORATIVE STATE OF IRRIGATIVE SOILS OF THE MUGHAN PLAIN DEPENDING ON SALINIZATION DEGREE AND TYPE
}

\begin{abstract}
The article is dedicated to the agromeliorative measures system prepared for the meliorative state improvement of these soils on the bases of the researches performed in the solonetzificated and salinized to a different degree in the MughanSalyan massive of the Kur-Araz lowland.

During the researches the slope depth of subsoil waters and mineralization dynamics were studied, the salts quantity and type was fixed in the soil, therefore the full and subtle water weight was performed in the samples taken from the experimental area.

Key words: salinity; salinized; solonetzificated; ameliorative state; collectordrainage net; ground water
\end{abstract}

\section{Formulation of the problem}

As a result of agrarian reforms in the republic the new attitudes were created in Land use, the soils were given to the different farm forms.

Preparation of the agro-meliorative measures system on the basis of the researches performed in the areas salinized and solonetzificated to a different degree will serves improvement of ameliorative state in these soils. All the researches have been performed in the selected areas of the characteristic places in the Mughan plain. Depth of the soils salinity was defermined from soil sections till 2,0 m on genetic layers and sometimes in the soil samples taken from every $50 \mathrm{sm}$.

During the researches the samples were taken from subsoil waters which have been observed in the characteristic cuts with the purpose of investigation of the slope depth and mineralization dynamics in subsoil waters from the experimental area and their mineralization and type have been fixed.

(C) M.G. Mustafayev, B.M. Mammadov, N.M. Huseynova, 2019 
To fix a quantity and a type of salts in the soil full and subtle water weight analysis was performed in the samples taken from the soil sections possessing different salinity in the experimental field.

\section{Relevance of research}

At present till 570000 hectares of the irrigative area more than 1,43 million hectares exposed to salinization to a different degree in the republic. 375000 hectares of these soils are weak, 165000 hectares are mean and strong salinization [1].

To meet the population's need rising for food products, an improvement of ameliorative state of the same soils remains current.

\section{The object and methods of research}

Salinized and solonetzificated sowing areas to a various degree in Mugan-Salyan massive of the Kur-Araz lowland have been adopted as a research object to study meliorative state of the irrigative soils in the Mughan plain. The soil and water analysis were performed by the general method (Arinushkin's method).

Preparation of the measures system for improvement of the same soils and definition of ecomeliorative state of soils (fertility indicators, an available condition of the collector-drainage and irrigation systems, change dynamics of water mineralization and experiment) in the experimental soils is a main problem.

As a result of an accumulative activity of the Kur-Araz rivers the relief in the Mughan plain was created and its formation was continuing up to now up to now. Here an alluvial-accumulative forms (tough and high coast, ancient deep river-beds, coast ways and etc.) of the relief are available.

Geology of the research zone concerns the background of the general historical geotectorics in the Caspean Sea, north and south zones fell down, Alazan-Ayrichay and Kur depression was created. A climate of Mughan concerns the subtropic semidesert arid climate group [2]. An average annual temperature is $+14,1^{\circ} \mathrm{C}$, a relative humidity of the air is $60 \%$, a yearly quantity of the atmospheric precipitations is $246-260 \mathrm{~mm}$, annual evaporation from water surface reaches $950 \mathrm{~mm}$. An average monthly temperature of the soil surface is $0,6^{\circ} \mathrm{C}$ in January, $+18,9^{\circ} \mathrm{C}$ in July-August $[3,4]$. The plant-cover in the plain concerns semidesert type, mainly three kinds: wormwood, saline and herbaceous plants. Here heat-loving annual plants, including cotton planting is considered rational for the climate condition. The various kind of the plants are grown in a great part of the zone and they changed. At present natural plants are found in some places $[2,5]$.

The soil cover of the plain was learnt Y.A. Kamensky, S.A. Zakharov, S.I. Tyuramnov. The following soil types have been determined: little humic greymeadow, mean humic grey-meadow, high humic grey-meadow, primitive-grey, meadowgrey soils $[2,4]$.

Recently the main reasons of the land salinization in the Kur-Araz lonland soil salinization was revealend by V.R. Volobuyev, M.E. Salayev, G.Sh. Mammadov, M.P. Babayev and others. The authors seperated into meadow grey soils, salinelike, solonchaklike, marlaceous, gleyed, irrigating species and noted us of these soils under cotton, grain and orchard plants. But in the amelioration field V. Volobuyev, M. Abduyev, Kh. Jafarov, G. Azizov, M. Mustafayev and others attracted an attention for investigation of the salinization changes occuring in use period of them $[4,5,7]$. 
The soils in the plain are wholly fertile and good for cultivation. But the soils of which water-physical characters are usatisfactory aren't little. A main reason of difficulty of the sustainable product getting and obstacle of the agriculture development is presence of more salts. Distribution of salts on salinity gradation in the Mughan plain is as the folloning according to G.Z. Azizov and A.M. Gadimov $[1,4]$.

Table 1 - Distribution of the Mughan plain soils on salinity gradation, $\frac{\text { thous } \mid h}{\%}$

\begin{tabular}{|l|c|c|c|c|c|c|}
\hline Salinity gradation, \% & $<0,25$ & $0,25-0,50$ & $0,50-1,00$ & $1,00-2,00$ & $>2,00$ & Sum \\
\hline Area, $\frac{\text { thous }, \mathrm{h}}{\%}$ & $\frac{117,1}{24,5}$ & $\frac{49,8}{10,4}$ & $\frac{78,6}{16,4}$ & $\frac{137,3}{28,7}$ & $\frac{95,6}{20,0}$ & $\frac{478,4}{100,0}$ \\
\hline
\end{tabular}

Note: Salinity of the unsalinized soils less than $0,5 \% 166,9$ hectares, salinized (salinity more than $0,5 \%$ ) soils are 311500 hectares.

Change of granulometric composition in the research lands is as the following on the table, it is seen from the table that a quantity of the particles (physical gley), less than $0,01 \mathrm{~mm}$ chandes by $52,64-68,58 \%$, along the profile. The soils are mean andheavy loamy by a granulometric composition.

Table 2 - Granulometrik composition of the soil samples, \% (2018 year)

\begin{tabular}{|c|c|c|c|c|c|c|c|c|}
\hline \multirow{2}{*}{$\begin{array}{c}\text { Number } \begin{array}{c}\text { of } \\
\text { section }\end{array} \\
\text { s }\end{array}$} & $\begin{array}{c}\text { Depth, } \\
\mathrm{cm}\end{array}$ & $\begin{array}{c}1,0- \\
0,25\end{array}$ & $\begin{array}{c}0,25- \\
0,05\end{array}$ & $\begin{array}{c}0,05- \\
0,01\end{array}$ & $\begin{array}{c}0,01- \\
0,005\end{array}$ & $\begin{array}{c}0,005- \\
0,001\end{array}$ & $<0,0001$ & $<0,001$ \\
\hline \multirow{4}{*}{ M-3 } & $0-50$ & 0,79 & 16,71 & 25,09 & 14,92 & 19,58 & 22,92 & 57,41 \\
\cline { 2 - 9 } & $50-100$ & 0,83 & 26,79 & 21,78 & 15,04 & 16,32 & 19,24 & 50,60 \\
\cline { 2 - 9 } & $100-150$ & 0,65 & 22,39 & 24,32 & 16,28 & 17,84 & 18,52 & 52,64 \\
\cline { 2 - 9 } & $150-200$ & 0,61 & 22,71 & 23,16 & 14,62 & 18,86 & 20,04 & 53,52 \\
\hline \multirow{4}{*}{ M-5 } & $0-50$ & 0,40 & 14,20 & 24,67 & 10,89 & 26,22 & 23,67 & 60,73 \\
\cline { 2 - 9 } & $50-100$ & 0,25 & 18,17 & 27,04 & 12,08 & 23,34 & 19,12 & 54,54 \\
\cline { 2 - 9 } & $100-150$ & 0,22 & 7,14 & 24,06 & 18,24 & 27,62 & 42,72 & 68,58 \\
\cline { 2 - 9 } & $150-200$ & 0,38 & 14,52 & 19,70 & 8,66 & 26,64 & 30,10 & 65,40 \\
\hline
\end{tabular}

The salts quantity, ground and irrigative waters mineralization was fixed in the soils of the experimental area. As a result of the analyses it was determined that $\mathrm{CO}_{3}$ ion wasn't observed in the soil samples taken from the zone.

$\mathrm{HCO}_{3}$ ion vibrated by $0,012-0,102 \%$. A quantity of $\mathrm{Cl}$ ion was $0,016-0,255 \%$. But $\mathrm{SO}_{4}$ ion number changed by $0,058-0,775 \%$ a long the profile. But the salts quantity in these samples (for the dry residue) was 0,206-0,733\% (Table 3).

Table 3 - Quantity of salts in the irrigated meadow-grey soils of the experimental area in the Mughan plain, $\frac{\%}{m g \cdot e k v}$

\begin{tabular}{|c|c|c|c|c|c|c|}
\hline $\begin{array}{c}\text { Number of } \\
\text { section }\end{array}$ & $\begin{array}{c}\text { Depth, } \\
\text { cm }\end{array}$ & $\mathrm{CO}_{3}$ & $\mathrm{HCO}_{3}$ & $\mathrm{SO}_{4}$ & $\mathrm{Cl}$ & $\begin{array}{c}\text { Dry residue, } \\
\%\end{array}$ \\
\hline 1 & 2 & 3 & 4 & 5 & 6 & 7 \\
\hline \multirow{3}{*}{$\mathrm{M}-1$} & $0-50$ & No & $\frac{0,065}{1,06}$ & $\frac{0,775}{1,62}$ & $\frac{0,255}{0,72}$ & 0,254 \\
\cline { 2 - 7 } & $50-100$ & No & $\frac{0,093}{1,52}$ & $\frac{0,058}{1,21}$ & $\frac{0,016}{0,44}$ & 0,228 \\
\hline
\end{tabular}


Continuation Table 3

\begin{tabular}{|c|c|c|c|c|c|c|}
\hline 1 & 2 & 3 & 4 & 5 & 6 & 7 \\
\hline \multirow{3}{*}{ M-1 } & $100-150$ & No & $\frac{0,090}{1,48}$ & $\frac{0,068}{1,42}$ & $\frac{0,018}{0,52}$ & 0,292 \\
\cline { 2 - 7 } & $150-200$ & No & $\frac{0,102}{1,76}$ & $\frac{0,074}{1,54}$ & $\frac{0,021}{0,60}$ & 0,306 \\
\hline \multirow{4}{*}{ M-3 } & $0-50$ & No & $\frac{0,017}{0,28}$ & $\frac{0,276}{5,74}$ & $\frac{0,058}{1,62}$ & 0,518 \\
\cline { 2 - 7 } & $50-100$ & No & $\frac{0,012}{0,20}$ & $\frac{0,362}{7,53}$ & $\frac{0,074}{2,03}$ & 0,570 \\
\cline { 2 - 7 } & $100-150$ & No & $\frac{0,024}{0,40}$ & $\frac{0,203}{4,23}$ & $\frac{0,028}{0,80}$ & 0,276 \\
\cline { 2 - 7 } & $150-200$ & No & $\frac{0,029}{0,48}$ & $\frac{0,101}{2,11}$ & $\frac{0,028}{0,80}$ & 0,206 \\
\hline \multirow{3}{*}{ M-5 } & $0-50$ & No & $\frac{0,018}{0,30}$ & $\frac{0,210}{4,38}$ & $\frac{0,228}{6,44}$ & 0,733 \\
\cline { 2 - 7 } & $50-100$ & No & $\frac{0,019}{0,32}$ & $\frac{0,167}{3,48}$ & $\frac{0,214}{6,04}$ & 0,578 \\
\cline { 2 - 7 } & $100-150$ & No & $\frac{0,019}{0,32}$ & $\frac{0,177}{3,70}$ & $\frac{0,229}{6,44}$ & 0,654 \\
\cline { 2 - 7 } & $150-200$ & No & $\frac{0,022}{0,36}$ & $\frac{0,128}{2,67}$ & $\frac{0,203}{5,72}$ & 0,554 \\
\hline
\end{tabular}

It is seen from the given results thah the salts number begins to increase towards the low layers. So the soils of the experimental area aren't salinized, they are salinized to a mean and weak degree.

The ground waters are near the surface in the Mughan zone, the nourisment sources are the followings: irrigative waters, atmospheric precipitations, infiltration waters from the rivers and canals, underground pressure waters and etc. Nourishment at the expense of rain waters forming $8-10 \%$ fromtotality occurs in the spring and autumn seasons. There are pressure waters in the zone and they are connected with the ground waters. The same waters are $15-17 \%$ of the inome part in water balance. The ground waters level reaches 1,0-1,5 $\mathrm{m}$. These waters are hydrocalcareous for the chemical composition. The chlorine and sulphate types are found in some places $[1,3,6]$.

Mineralization of ground waters in the experimental area is as the following table:

Table 4 - Mineralization of ground waters in the experimental area, $\frac{\mathrm{q} \mid \mathrm{l}}{\text { mq.ekv }}$

\begin{tabular}{|c|c|c|c|c|}
\hline $\begin{array}{c}\text { Number of } \\
\text { section }\end{array}$ & $\mathrm{CO}_{3}$ & $\mathrm{HCO}_{3}$ & $\mathrm{Cl}$ & Dry residue, $\mathrm{q} \mid 1$ \\
\hline M-1 & No & $\frac{0,018}{0,30}$ & $\frac{0,187}{5,32}$ & 2,215 \\
\hline M-2 & No & $\frac{0,027}{0,45}$ & $\frac{0,203}{5,80}$ & 2,435 \\
\hline M-3 & No & $\frac{0,031}{0,50}$ & $\frac{0,248}{7,10}$ & 2,873 \\
\hline
\end{tabular}

Mineralization of the subsoil waters in the research zone is different in these cuts: 2,215-2,873 g|l. $\mathrm{CO}_{3}$ ion wasn't observed in anion content of these samples. A quantity of $\mathrm{HCO}_{3}$ ion is $0,018-0,031 \mathrm{~g} / \mathrm{l}$ but $\mathrm{Cl}$ ion changed $0,187-0,248 \mathrm{~g} / \mathrm{l}$. The 
salts type soil was determined in available classifications. $\mathrm{Cl}$ ion number in this soil is $10-23 \%$ and $25-34 \%$, the salt type is chlorine-sulphatic and sulphatic-chlorine in some places because $\mathrm{Cl} \mid \mathrm{SO}_{4}$ ratio is 1,0-0,2 and 2,0-1,0.

The salts quantity in soil is $0,206-0,733 \%$ for dry residue, humus number is $2,78-0,61 \%, \mathrm{pH}$ is 7,6-8,5 along profile.

The experiments show that each agromeliorative measure performing with the purpose of fertility increase, displacement of the harmful waters and decrease of the salt quantity in soils causes improvement of the meliorative state of the same soils, increase of the sowing area productivity. The complex measures performed with the purpose of improvement of the ameliorative state in the soil areas good for sowing, provision of the plant productivity.

\section{Conclusion}

The researches show that $\mathrm{CO}_{3}$ ion in the salts content wasn't observed along the profile in the areas where the collector-drainage system is satisfactory in the Mughan plain. $\mathrm{HCO}_{3}$ ion is $0,012-0,102 \%, \mathrm{SO}_{4}$ ion $-0,058-0,775 \%, \mathrm{Cl}$ ion $-0,016-0,255 \%$. The salts quantity for dry residue in soil is $0,206-0,733 \%$ and chlorine-sulphatic for $\mathrm{Cl} \mid \mathrm{SO}_{4}$ ratio. The soils in the Mughan plain are unsalinized, weak and mean salinized for these indices. The soils are mean and heavy loamy for granulometric composition. A quantity of physical clay is 52,64-68,58\%, $\mathrm{pH}$ number is 7,6-8,5, humus quantity changes by $2,78-0,61$ in soil solution along profile. The ground water mineralization is 2,2-2,9 $\mathrm{g} \mid \mathrm{l}$ in these areas. The agromeliorative and ameliorative measures which will be performed against salinization and swamping by fulfilling provision of the tillage areas with irrigative water for the purpose of improvement of the soils ameliorative state in the areas good for sowing will swerve increase of soils fertility and agricultural plants productivity.

\section{REFERENCES}

1. Mustafayev, M. G. (2012). Study of the water-salt balance in the ameliorated soils of the Mughan plain. In Scientific Works collection of A S (Vol. XXXII, pp. 87-92). Baku, Azerbaijan: Elm.

2. Abduev, M. R. (n.d.). Delluvial shaped salinized soils of the Azerbaijan plain part. (pp. 17-124). Baku: "CBS Poligraphy Production".

3. Abduev, M. R. (2012). Delluvial shaped salinized soils and melioration problems. Baku: Elm.

4. Jafarov, K. F. (2000). Azerbaijan soils melioration. Baku: Elm.

5. Azizov, G. Z. (2006). Water-salt balance and scientific analysis of its results in ameliorated soil-ground waters of the Kur-Araz valley. Baku: Elm.

6. Azizov, G. Z., \& Guliyev, A. G. (1999). Azerbaijan salinized soils, increase methods of their amelioration and fertility. Baku: Az. IMU.

7. Azizov, G. Z., \& Mustafayev, M. G. (2010). Change of mineralization and pla-cement depth of subsoil waters in the Mughan-Salyan massive. In Works collection of Azerbaijan Soil Scientists' Society (Vol. XI, pp. 31-38). Baku, Azerbaijan.

The article was received 17.07.2019 and was accepted after revision 14.08.2019 
М.Г. Мустафаєв, Б.М. Мамедов, Н.М. Гусейнова

МЕЛІОРАТИВНИЙ СТАН ЗРОШУВАНИХ ГРУНТІВ МУГАНСБКОЇ РІВНИНИ В ЗАЛЕЖНОСТІ ВІД СТУПЕНЯ І ТИПУ ЗАСОЛЕННЯ

Анотація. Стаття присвячена системі агромеліоративних заходів, розроблених для поліпшення меліоративного стану цих грунтів на основі досліджень, проведених в солонцюватих і засолених грунтах різного ступеня Мугано-Сальянського масиву Кура-Аразської низовини Азербайджану.

В ході досліджень були вивчені глибина залягання грунтових вод і динаміка мінералізації, кількість і тип солей в грунті. Для цього в зразках, взятих $з$ дослідної ділянки, була виконана повна водна витяжка.

Ключові слова: мінералізація; засолення; солонцюватість; меліоративний стан, колекторно-дренажна мережа; грунтові води

\section{Мустафаєв Мустафа Гілман огли}

доктор аграрних наук, доцент Інституту наук про грунти та агрохімії Національної академії наук Азербайджану

Адреса робоча: AZ1073 Азербайджан, м. Баку, вул. М. Рагіма, 5

e-mail: meliorasiya58@mail.ru

ORCID ID 0000-0003-2071-3078

\section{Мамедов Бахтіяр Мурсал огли}

кандидат технічних наук, Інститут наук про грунти та агрохімії Національної академії наук Азербайджану

Адреса робоча: AZ1073 Азербайджан, м. Баку, вул. М. Рагіма, 5

e-mail: meliorasiya58@mail.ru

\section{Гусейнова Ніса Мустафа}

науковий співробітник Інституту наук про грунти та агрохімії Національної академії наук Азербайджану

Адреса робоча: AZ1073 Азербайджан, м. Баку, вул. М. Рагіма, 5

e-mail: meliorasiya58@mail.ru 